\title{
Correction to: Running on a high: parkrun and personal well-being
}

\author{
Anne Grunseit ${ }^{*}$, Justin Richards ${ }^{1}$ and Dafna Merom²
}

\section{Correction to: BMC Public Health \\ https://doi.org/10.1186/s12889-017-4620-1}

It was highlighted that the original article [1] contained an error in the proportions reported in the Results, in the Representativeness of registered parkrunners section. This Correction article shows the incorrect and correct statement.

\section{Incorrect:}

With respect to age, the survey over-represented the three age groups 35-44, 45-49, 50-54 years compared with registrants $(35.8 \%$ vs. $18.4 \%, 16.2 \%$ vs. $6.1 \%, 11.5 \%$ vs. $4.1 \%$, and underrepresented the three age groups $18-24,55-64,65$ or older ( $2.4 \%$ vs. $6.3 \%$; $10.8 \%$ vs. $35 \%$; $3.7 \%$ vs. $10.3 \%) p<0.001$. For both the survey sample and parkrun registrants the 25-34 year-old group comprised $20 \%$.

\section{Correct:}

With respect to age, the survey over-represented the five age groups $35-44,45-54,55-64$ years, compared with registrants $(35.8 \%$ vs. $31.0 \%, 27.6 \%$ vs. $17.2 \%, 10.8 \%$ vs. $5.9 \%, 3.7 \%$ vs $1.7 \%$ respectively), and underrepresented the two age groups $18-24$ and $25-34$ years $(2.4 \%$ vs. $10.7 \% ; 19.7 \%$ vs. $33.6 \%$ respectively) $p<0.001$.

\section{Author details}

'Prevention Research Collaboration, Sydney School of Public Health, University of Sydney, Level 6, The Hub, Charles Perkins Centre (D17), Sydney, NSW 2006, Australia. ${ }^{2}$ Physical Activity and Health, Western Sydney University, Locked Bag 1797, Penrith, NSW 2751, Australia.

Published online: 16 October 2019

\section{Reference}

1. Grunseit, et al. Running on a high: parkrun and personal well-being. BMC Public Health. 2017;18:1. https://doi.org/10.1186/s12889-017-4620-1

\footnotetext{
* Correspondence: anne.grunseit@sydney.edu.au

'Prevention Research Collaboration, Sydney School of Public Health, University of Sydney, Level 6, The Hub, Charles Perkins Centre (D17), Sydney, NSW 2006, Australia

Full list of author information is available at the end of the article
}

(c) The Author(s). 2019 Open Access This article is distributed under the terms of the Creative Commons Attribution 4.0 International License (http://creativecommons.org/licenses/by/4.0/), which permits unrestricted use, distribution, and reproduction in any medium, provided you give appropriate credit to the original author(s) and the source, provide a link to the Creative Commons license, and indicate if changes were made. The Creative Commons Public Domain Dedication waiver (http://creativecommons.org/publicdomain/zero/1.0/) applies to the data made available in this article, unless otherwise stated. 